\title{
Correction to: Thiol-Redox Proteomics to Study Reversible Protein Thiol Oxidations in Bacteria
}

\author{
Martina Rossius, Falko Hochgräfe, and Haike Antelmann
}

Correction to:

Chapter 18 in: Dörte Becher (ed.), Microbial Proteomics:

Methods and Protocols, Methods in Molecular Biology, vol. 1841, https://doi.org/10.1007/978-1-4939-8695-8_18

This protocol was originally published (c) Springer Science+Business Media, LLC, part of Springer Nature 2018, but has now been made available (C) The Author(s) under a CC BY 4.0 license. 